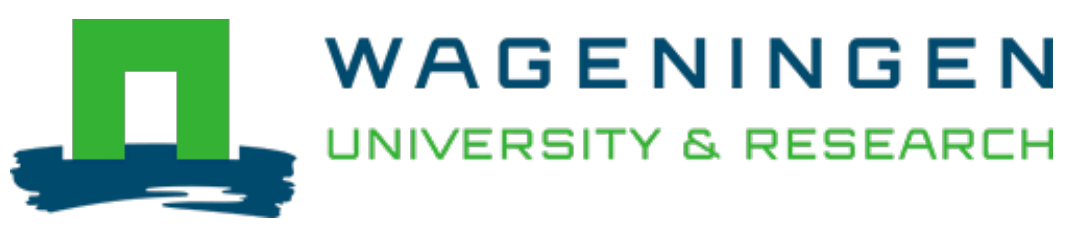

\title{
Disentangling the direct and indirect effects of cropland abandonment on soil microbial activity in grassland soil at different depths
}

\section{Catena}

Xu, Hongwei; Qu, Qing; Chen, Yanhua; Wang, Minggang; Liu, Guobin et al

https://doi.org/10.1016/j.catena.2020.104774

This article is made publicly available in the institutional repository of Wageningen University and Research, under the terms of article $25 \mathrm{fa}$ of the Dutch Copyright Act, also known as the Amendment Taverne. This has been done with explicit consent by the author.

Article 25 fa states that the author of a short scientific work funded either wholly or partially by Dutch public funds is entitled to make that work publicly available for no consideration following a reasonable period of time after the work was first published, provided that clear reference is made to the source of the first publication of the work.

This publication is distributed under The Association of Universities in the Netherlands (VSNU) 'Article $25 \mathrm{fa}$ implementation' project. In this project research outputs of researchers employed by Dutch Universities that comply with the legal requirements of Article $25 \mathrm{fa}$ of the Dutch Copyright Act are distributed online and free of cost or other barriers in institutional repositories. Research outputs are distributed six months after their first online publication in the original published version and with proper attribution to the source of the original publication.

You are permitted to download and use the publication for personal purposes. All rights remain with the author(s) and / or copyright owner(s) of this work. Any use of the publication or parts of it other than authorised under article $25 \mathrm{fa}$ of the Dutch Copyright act is prohibited. Wageningen University \& Research and the author(s) of this publication shall not be held responsible or liable for any damages resulting from your (re)use of this publication.

For questions regarding the public availability of this article please contact openscience.library@,wur.nl 


\title{
Disentangling the direct and indirect effects of cropland abandonment on soil microbial activity in grassland soil at different depths
}

\author{
Hongwei Xu ${ }^{\mathrm{a}, \mathrm{b}}$, Qing $\mathrm{Qu}^{\mathrm{c}}$, Yanhua Chen ${ }^{\mathrm{d}}$, Minggang Wang ${ }^{\mathrm{e}}$, Guobin Liu ${ }^{\mathrm{a}, \mathrm{b}, \mathrm{c}}$, Sha Xue ${ }^{\mathrm{a}, \mathrm{b}, \mathrm{c}, *}$, \\ Xiaomei Yang ${ }^{\mathrm{a}, \mathrm{c}, \mathrm{f}}$ \\ a State Key Laboratory of Soil Erosion and Dryland Farming on the Loess Plateau, Institute of Soil and Water Conservation, Chinese Academy of Sciences and Ministry of \\ Water Resources, Yangling, Shaanxi 712100, PR China \\ ${ }^{\mathrm{b}}$ University of Chinese Academy of Sciences, Beijing 100049, PR China \\ ${ }^{\mathrm{c}}$ State Key Laboratory of Soil Erosion and Dryland Farming on Loess Plateau, Institute of Soil and Water Conservation, Northwest A \& F University, Yangling, Shaanxi \\ 712100, PR China \\ ${ }^{\mathrm{d}}$ Institute of Plant Nutrition and Resources, Beijing Academy of Agricultural and Forestry Sciences, Beijing 100097, China \\ ${ }^{\mathrm{e}}$ Research Center of Forest Management Engineering of State Forestry and Grassland Administration, Beijing Forestry University, Beijing 100083, PR China \\ ${ }^{\mathrm{f}}$ Soil Physics and Land Management, Wageningen University \& Research, 6700AA Wageningen, The Netherlands
}

\section{A R T I C L E I N F O}

\section{Keywords:}

Plant-soil interactions

Vegetation restoration

Soil enzyme activity

Soil nutrients

Structural equation models

\begin{abstract}
A B S T R A C T
Cropland abandonment strongly affects plant-soil interactions. However, knowledge remains limited about how the production and diversity of plants and soil physicochemical parameters drive changes in soil microbial activity (such as microbial biomass, respiration, and enzyme activity) after cropland abandonment. Here, we investigated a grassland restoration chronosequence (0-30 years) to determine the dynamics of soil microbial biomass, respiration, and enzyme activity in the Loess Hilly, Region (China). Overall, cropland abandonment caused an increase in soil microbial activity primarily in the $0-20 \mathrm{~cm}$ soil layers. The metabolic quotient in the 0-10 cm layer decreased linearly with time since abandonment (recovery years). Structural equation models showed that recovery years directly and indirectly affected changes to soil microbial activity. Plant species richness, aboveground biomass, and soil organic carbon explained a large proportion of the variability in soil microbial activity in the $0-20 \mathrm{~cm}$ layer. However, the variability in soil microbial activity was mostly explained by plant species richness, belowground biomass, and soil total nitrogen in the $20-50 \mathrm{~cm}$ layers. Our results indicate that during recovery after cropland abandonment, changes in soil microbial activity are driven by plant characteristics and soil physicochemical parameters, with different drivers at different soil depths.
\end{abstract}

\section{Introduction}

Cropland abandonment is an effective way to improve soil quality (Chang et al., 2017). However, cropland abandonment directly and negatively affects the quality and quantity cultivated land, subsequently impacting national food security and social stability (Raj and Watanabe, 2006). The process of cropland abandonment could help to improve the productivity of land, along with slowing soil and water loss, which could have important practical significance for improving the ecology of the natural environment (Raj and Watanabe, 2006). However, such improvement highly depends on well programmed and managed cropland abandonment strategies for some years, such as soil and water conservation techniques to avoid land degradation (Shi and Shao, 2000).

Soil microbial biomass refers to the total amount of living microorganisms living in the soil (Jenkinson et al., 2004). It is highly dynamic and is related to soil carbon, nitrogen, and phosphorus cycling (Jenkinson et al., 2004; Yevdokimov et al., 2016). Soil enzymes are mainly derived from root exudates, litter, and microorganisms (Nannipieri et al., 2018; Pausch and Kuzyakov, 2018). Soil respiration regulates the key processes that facilitate ecosystem functioning (Singh et al., 2010). Soil microorganisms play a functional role in the cycling of nutrients in ecosystems (Geisseler and Scow, 2014). Soil microbial activity is an important indicator of soil fertility and quality (Geisseler and Scow, 2014; Kristiina et al., 2014; Yevdokimov et al., 2016). Soil respiration is closely related to microbial activity and reflects the functional characteristics of soil microbial communities. Therefore, it has been widely used in the evaluation of soil ecosystems and soil quality (Singh et al., 2010). Nutrient cycling by soil microorganisms, for example, the decomposition of plant litter into soil nutrients, is

\footnotetext{
* Corresponding author at: Institute of Soil and Water Conservation, Northwest A \& F University, Yangling PR China.

E-mail address: xuesha100@163.com (S. Xue).
} 


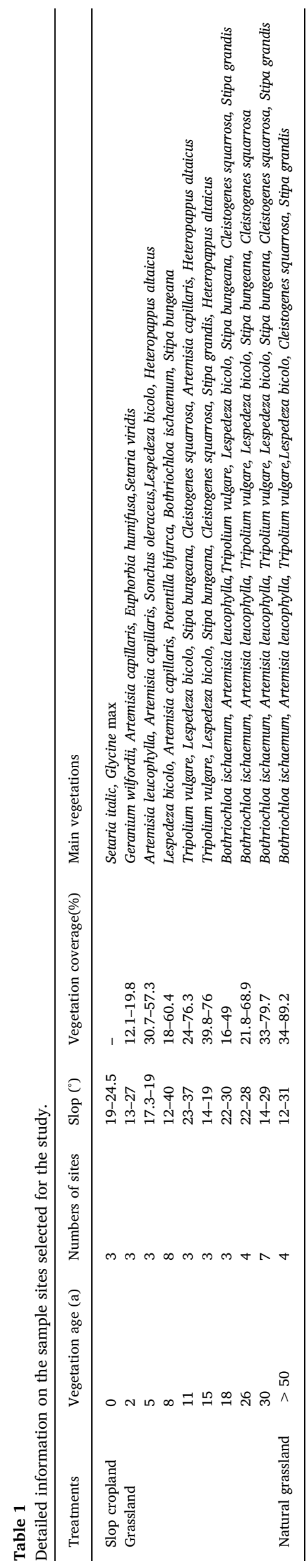

important for vegetation growth (Liang et al., 2017; Spohn et al., 2016). Soil enzymes play an important role in this process (Mooshammer et al., 2014). Therefore, the study of soil microbial activity can be used to explore and analyze the structure and function of soil ecosystems, crop yield, and sustainable use of soil.

Soil microbial activity is strongly affected by vegetation restoration and has been found to gradually improve along a revegetation chronosequence (Zhang et al., 2019; Zhu et al., 2019; Xiao et al., 2020; Xu et al., 2020a). Meanwhile, many studies have shown that precipitation (Na et al., 2019), vegetation type (Sinha et al., 2009), soil type (Cui et al., 2018), and soil depth (de Medeiros et al., 2017) strongly influence soil microbial activity.

However, the mechanisms driving changes to soil microbial activity in response to cropland abandonment remain poorly understood. Various studies have demonstrated that the plant biomass, plant diversity, and soil nutrient concentrations in grasslands significantly increase after abandonment (Cui et al., 2019; Liu et al., 2017). Through a meta-analysis, Chen et al. (2019) showed that plant diversity is positively correlated with soil microbial biomass. Another study showed that the species richness and biomass of plants significantly affect soil microbial composition, enzyme activity, and respiration (Zhu et al., 2019). However, knowledge remains limited on how soil microbial activity changes in relation to soil and plant community characteristics at different soil depths.

Since the beginning of the 20th century, the natural environment of the Loess Plateau has been subjected to increasing degradation due to increasing human population and unregulated development and utilization of land resources. These activities have reduced vegetation coverage and caused major soil erosion. To reduce soil erosion, and improve vegetation coverage, soil quality, vegetation productivity, and soil sustainability, China began implementing the "Grain for Green" project in 1999. Cropland abandonment is one of the main measures that has been implemented to restore vegetation in this region.

Existing research and theories have demonstrated that cropland abandonment enhances soil microbial activity in grasslands (Cui et al., 2019; Xiao et al., 2020); however, knowledge remains limited on how these effects are indirectly mediated by the productivity and diversity of plants and soil physicochemical parameters. Therefore, our aim is to address the following questions: (1) how the productivity and diversity of plants and soil physicochemical parameters drive changes of soil microbial activity along a grassland restoration chronosequence, and (2) whether these changes vary with soil depth. We hypothesized that: (1) the number of years since abandonment (recovery years) had direct and indirect effects on soil microbial activity changes; (2) the indirect effect of recovery years is mainly through changes in plant characteristics and soil physicochemical parameters; and (3) both direct and indirect effects decrease with increasing soil depth, owing to a decrease in influencing factors with depth.

\section{Materials and methods}

\subsection{Study site}

This study was conducted at the Zhifanggou watershed on the central Loess Plateau, China ( $36^{\circ} 51^{\prime} \mathrm{N}, 109^{\circ} 19^{\prime} \mathrm{E}$; $1010-1400 \mathrm{~m}$ above sea level [a.s.l.]). This region covers $8.27 \mathrm{~km}^{2}$ and is a national demonstration area for China's "Grain for Green" program. This area has a warm temperate and semi-arid climate. The annual average precipitation is $483 \mathrm{~mm}$, and the annual average temperature is $8.8^{\circ} \mathrm{C}$. The watershed is characterized by vertical and horizontal gullies, broken terrain, and sparse vegetation. The soil type is mainly loess soil, which has a porous texture, and poor retention of water and fertilizer. The grass communities are dominated by Bothriochloa ischae, Stipa bungeana, Artemisia giraldii, and Artemisia gmelinii, depending on the stage of succession. 


\subsection{Study site selection}

To determine the dynamics of soil microbial activity after cropland abandonment, we adopted the "space for time" method in this study. Thirty-four grassland sites were selected, with eight age classes of abandonment (2, 5, 8, 11, 15, 18, 26, and 30 years since abandonment) (Table 1), for which detailed records had been collected by the local experimental station. In addition, three sloped cropland sites and four natural grassland (NG) sites (grassland for over 50 years) were selected to represent cropland before abandonment (age $=0$ years) and to assess the stage of recovery, respectively.

\subsection{Biomass sample collection}

First, three $2 \mathrm{~m} \times 2 \mathrm{~m}$ plots were randomly selected at each site. Sampling surveys were conducted to determine the direction of slope, along with information on the plant species present and their height and abundance. Aboveground biomass (AGB) and litter biomass (LB) were determined using the full access method at each plot. Belowground biomass (BGB) was determined by excavating roots from the $0-50 \mathrm{~cm}$ soil layer. Next, the samples were transferred to the laboratory. Roots were rinsed to remove attached soil particles. Then, all biomass samples were placed in an oven at $105^{\circ} \mathrm{C}$ for $5 \mathrm{~min}$ and further dried at $65^{\circ} \mathrm{C}$ until a constant weight was attained.

\subsection{Soil sample collection}

Soil bulk density was obtained using the ring knife method. In short, we use a ring knife to take soil samples from four soil depths $(0-10 \mathrm{~cm}$, $10-20 \mathrm{~cm}, 20-30 \mathrm{~cm}$, and $30-50 \mathrm{~cm}$ ) of two soil profiles (to $50 \mathrm{~cm}$ depth) in each plot. A soil drilling sampler (4-cm inner diameter) was used to sample soils from four depths in each plot. A random sampling method was adopted in this process. Fifteen samples were collected at each depth. Soil samples from the same plot and depth were mixed to form composite samples, and were transferred to the laboratory. Roots, stones, and visible animals were removed, and the soil samples were separated into two portions. One of the portions was used for the determination of soil organic carbon (SOC), total nitrogen (TN), and total phosphorus (TP). The other portion was kept at $4{ }^{\circ} \mathrm{C}$ and used to determine soil microbial biomass carbon (MBC), microbial biomass nitrogen (MBN), basal respiration (BR), saccharase activity (SA), urease activity (UA), phosphatase activity (PA), and catalase activity (CA).

\subsection{Laboratory analysis}

SOC and TN were measured using the Walkley and Black method and Kjeldahl method (Nelson and Sommers, 1982; Bremner et al., 1982), respectively. TP was measured using the ammonium molybdate method (Schade et al., 2003). Soil microbial biomass was measured using the fumigation extraction method (Vance et al., 1987). SA, UA, PA, and CA were determined using an assay modified from Guan (1986) as described by Wang et al. (2012) and Xue et al. (2017). BR was measured using the method described by Xue et al. (2017).

\subsection{Data analysis}

Following the description by Beijing (1995), plant diversity indexes were calculated as follows:

Shannon - Weinerdiversityindex $\left(\mathrm{H}^{\prime}\right)=-\sum p_{i} \ln p_{i}$

Pielou evenness index $(\mathrm{E})=\mathrm{H}^{\prime} / \operatorname{lgS}(2)$

Margalef richness index $(\mathrm{R})=(\mathrm{S}-1) / \operatorname{lgN}$ (3)where: $p_{i}$ is the relative importance of species $\mathrm{i} ; \mathrm{N}$ is the total number of species; and $\mathrm{S}$ is the number of species.

The metabolic quotient $\left(\mathrm{qCO}_{2}\right)\left(\mathrm{d}^{-1}\right)$ was calculated as described by
(Powlson and Jenkinson, 1976):

$\mathrm{qCO}_{2}=\frac{\mathrm{BR}}{\mathrm{MBC}}$

where: $\mathrm{BR}$ is the basal respiration ( $\mathrm{mg} \mathrm{kg}^{-1} \mathrm{~d}^{-1}$ ) and $\mathrm{MBC}$ is the soil microbial biomass carbon $\left(\mathrm{mg} \mathrm{kg}^{-1}\right)$.

\subsection{Statistical analysis}

To test whether MBC, MBN, BR, $\mathrm{qCO}_{2}$, SA, UA, PA, and CA differed statistically with years after abandonment (recovery years), one-way ANOVAs were used $(P<0.05)$. The distribution of all variables was assessed before the ANOVAs using the S-W test.

To further link soil microbial activity with plant productivity (AGB, $\mathrm{BGB}$, and LB, of which BGB was the total biomass in the $0-50 \mathrm{~cm}$ soil layers), and plant diversity ( $\mathrm{R}, \mathrm{E}$ and $\mathrm{H}^{\prime}$ ), and soil physicochemical properties (bulk density, SOC, TN, and TP of each soil depth), structural equation models (SEMs) were used. SEMs is a data analysis method where the model can be summarized using latent variables, with linear relationships existing between latent variables (Bollen, 1998). The latent variable of activity included $\mathrm{MBC}, \mathrm{MBN}, \mathrm{BR}, \mathrm{qCO}_{2}, \mathrm{SA}, \mathrm{UA}, \mathrm{PA}$, and CA. All sites were used in the SEMs except for the NG sites, as we cannot ensure the specific recovery year for these sites. Maximum likelihood (ML) was used to calculate the path coefficients between different variables.

Based on the SEMs, redundancy analysis (RDA) was selected to evaluate the associations between plant characteristics and soil physicochemical parameters, and species variables (MBC, MBN, soil BR, $\mathrm{qCO}_{2}$, SA, UA, PA and CA) at the four soil depths. Before conducting the $\mathrm{RDA}$, the gradient length was tested using detrended correspondence analysis (DCA). Detrended correspondence analysis and RDA were performed using CANOCO 5.0.

\section{Results}

3.1. Soil microbial biomass varied in relation to recovery years and soil depths

Overall, soil microbial biomass increased linearly with recovery years in the $0-20 \mathrm{~cm}$ layers (Fig. 1a, b). MBC increased from 35.08 to $244.95 \mathrm{mg} \mathrm{kg} \mathrm{kg}^{-1}$ soil in the $0-10 \mathrm{~cm}$ layer and from 35.91 to $130.36 \mathrm{mg} \mathrm{kg}^{-1}$ soil in the $10-20 \mathrm{~cm}$ layer. MBN increased from 17.55 to $32.62 \mathrm{mg} \mathrm{kg}^{-1}$ soil in the $0-10 \mathrm{~cm}$ layer and from 10.84 to $19.84 \mathrm{mg} \mathrm{kg}^{-1}$ soil in the $10-20 \mathrm{~cm}$ layer. Overall, soil microbial biomass decreased with increasing soil depth under all recovery years (Fig. 1a, b). In the $0-10 \mathrm{~cm}$ layer, the MBC and MBN of GL30 were lower than that in NG. Specifically, the MBC of GL30 accounted for $54.87 \%$ that of NG, while MBN accounted for $60.11 \%$ (Fig. 1c, d).

\section{2. $B R$ and $q \mathrm{CO}_{2}$ varied with recovery years and soil depths}

Overall, the BR of the $0-20 \mathrm{~cm}$ layers increased linearly over 30 years of abandonment, increasing from 39.36 to $61.48 \mathrm{mg} \mathrm{CO}_{2}-\mathrm{C}$ $\mathrm{kg}^{-1} \mathrm{~d}^{-1}$ in the $0-10 \mathrm{~cm}$ layer and from 40.86 to $51.55 \mathrm{mg} \mathrm{CO}_{2}-\mathrm{C} \mathrm{kg}^{-1}$ $\mathrm{d}^{-1}$ in the $10-20 \mathrm{~cm}$ layer (Fig. 2a). The $\mathrm{qCO}_{2}$ of grassland soils linearly decreased in the $0-10 \mathrm{~cm}$ layer over 30 years of abandonment, decreasing from 1.77 to $0.28 \mathrm{~d}^{-1}$ (Fig. 2b). Overall, soil BR decreased with soil depth for all recovery times (Fig. 2a, b). Across all four depths, the BR in the four soil depths of GL30 was significantly lower than that in NG. Specifically, the BR of GL30 accounted for 71.24\%, 77.26\%, $74.62 \%$, and $86.24 \%$ that of NG in the four layers, respectively (Fig. 2c). However, compared with $\mathrm{NG}, \mathrm{qCO}_{2}$ in the four soil depths of GL30 showed no significant difference (Fig. 2d). 

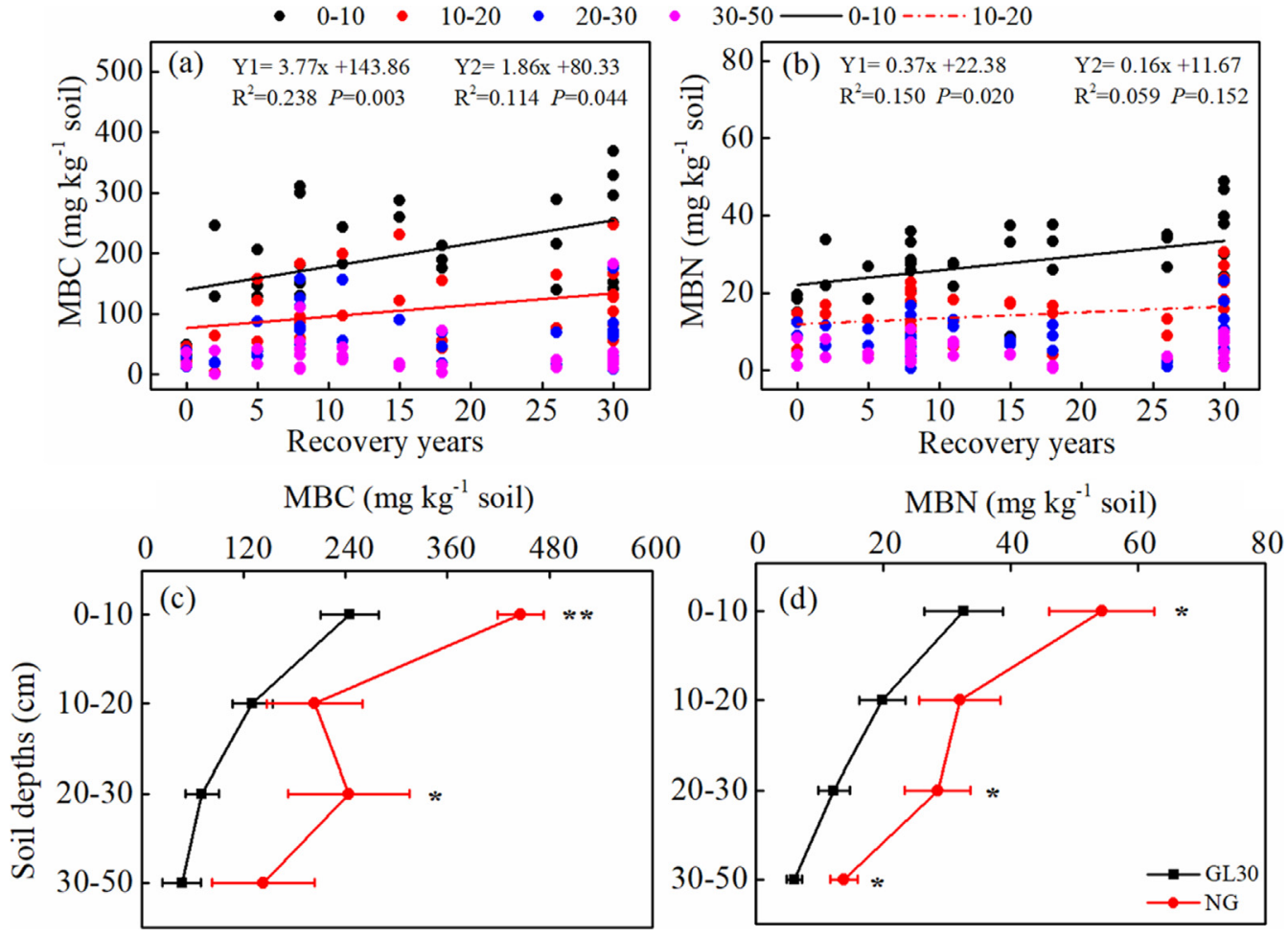

Fig. 1. Changes in (a) soil microbial biomass carbon (MBC) and (b) soil microbial biomass nitrogen (MBN) across the chronosequence; (c) MBC and (d) MBN at different soil depths in a grassland (GL) at 30 years of recovery compared to that in a natural grassland (NG). Note: * denotes significant differences at $P<0.05$; ** denotes significant differences at $P<0.01 ; \mathrm{Y} 1$ represents the linear regression of the 0-10 cm layer; Y2 represents the linear regression of the $10-20 \mathrm{~cm}$ layer; solid lines represent linear regressions that reached a significance level of $P<0.05$, and the dashed lines represent linear trends that have not reached statistical significance; un-regressed data points indicate that there is no obvious change across the recovery years.

\subsection{Soil enzyme activity varied with recovery years and soil depths}

SA and PA in the $0-30 \mathrm{~cm}$ layers, UA in the $0-20 \mathrm{~cm}$ layers, and CA in the $0-10 \mathrm{~cm}$ layer linearly increased with recovery years (Fig. 3a, b, c, d). In comparison, overall SA, UA, PA, and CA decreased with soil depth for all recovery times (Fig. 3a, b, c, d). The UA and PA of GL30 were significantly lower than those of NG in the $0-10 \mathrm{~cm}$ layer. Specifically, the UA of GL30 accounted for $74.56 \%$ of that of NG, while PA accounted for $73.09 \%$ (Fig. 4 b, c).

\subsection{Factor affecting patterns in soil microbial activity}

For the $0-10 \mathrm{~cm}$ layer, the SEMs explained $69 \%$ the variability in soil microbial activity. Recovery years indirectly affected soil microbial activity through R, AGB, LB, and SOC (Fig. 5a). For the 10-20 cm layer, the SEMs explained $53 \%$ of the variability in soil microbial activity. Similarly, recovery years indirectly affected soil microbial activity through R, AGB, LB, and SOC (Fig. 5b). In the 20-30 cm layer, the SEMs explained $33 \%$ of the variability in soil microbial activity. R, AGB, BGB,
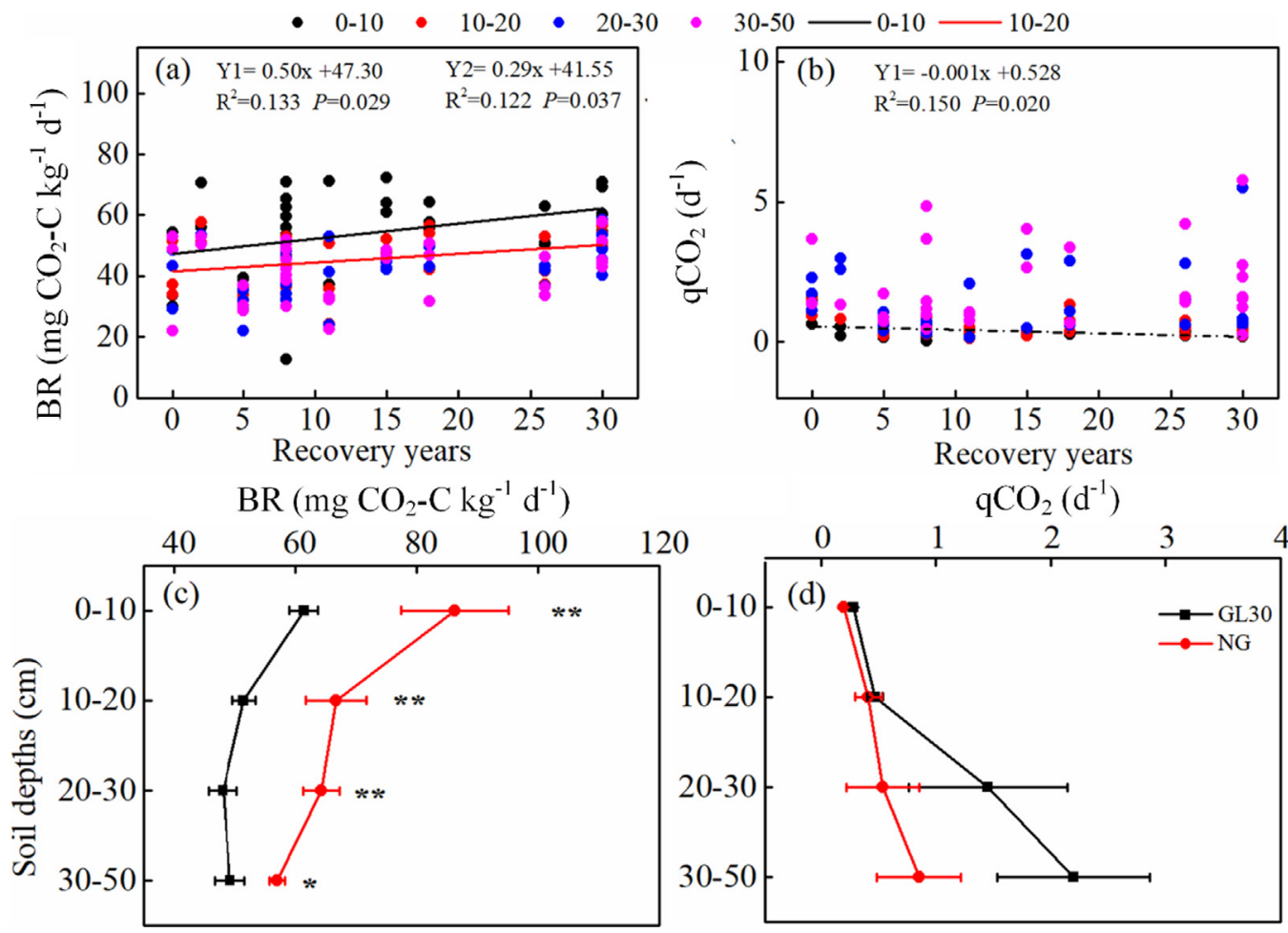

120

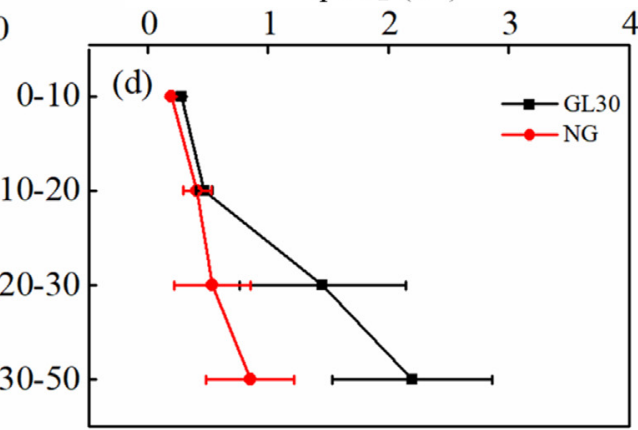

Fig. 2. Changes in (a) soil basal respiration (BR) and (b) metabolic quotient $\left(\mathrm{qCO}_{2}\right)$ across the chronosequence; (c) $\mathrm{BR}$ and (d) $\mathrm{qCO}_{2}$ at different soil depths in a grassland (GL) at 30 years of recovery compared to that in a natural grassland (NG). Note: * denotes significant differences at $P<0.05 ; * *$ denotes significant differences at $P<0.01$. ${ }^{* * *}$ denotes significant differences at $P<0.001$; Y1 represents a linear regression of the 0-10 cm layer; Y2 represents a linear regression at the $10-20 \mathrm{~cm}$ layer; solid lines represent linear regressions at a significant difference level of $P<0.05$, and the dashed line represent linear trends that have not reached statistical significance; un-regressed points indicate that there is no obvious linear change across the recovery years. 

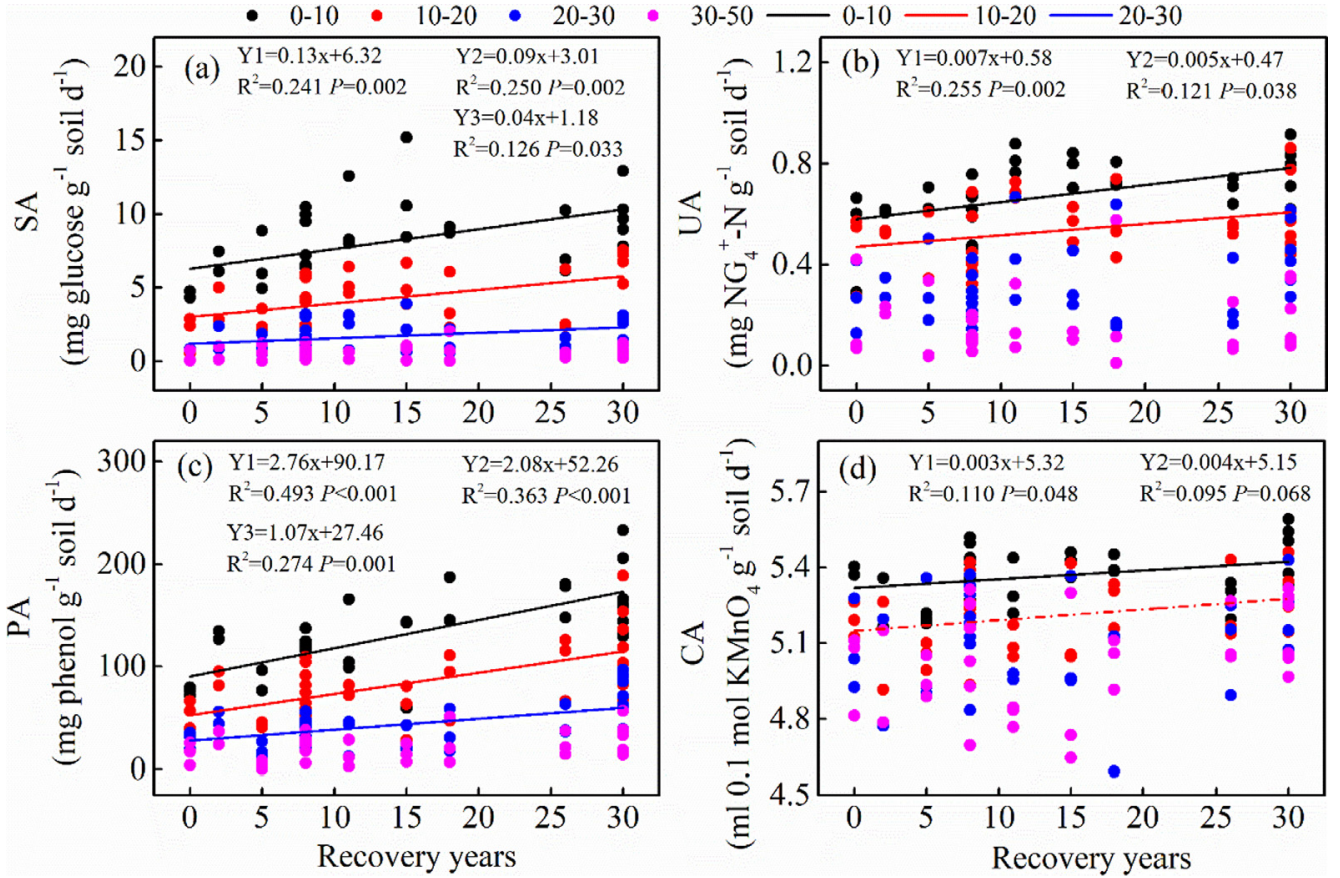

Fig. 3. Changes in (a) soil saccharase activity (SA), (b) soil urease activity (UA), (c) soil phosphatase activity (PA) and (d) soil catalase activity (CA) across the chronosequence. Note: Y1 represents linear regressions of the $0-10 \mathrm{~cm}$ layer; Y2 represents linear regressions of the 10-20 cm layer; Y3 represents linear regressions of the $20-30 \mathrm{~cm}$ layer; solid lines represent linear regressions that reached a significant difference level of $P<0.05$, and dashed lines represent trends across the chronosequence that have not reached statistical significance; un-regressed points represent factors that do not show any linear relationship across the recovery years. and TN directly affected soil microbial activity. Recovery years indirectly affected soil microbial activity through R, AGB, BGB, LB, TN, and SOC (Fig. 5c). The SEMs explained $8 \%$ of the variability in soil microbial activity for the $30-50 \mathrm{~cm}$ layer. R, BGB, and TN directly affected soil microbial activity. However, recovery years indirectly affected soil microbial activity through R, AGB, BGB, TN, and SOC (Fig. 5d).

\section{Discussion}

4.1. Dynamics of soil microbial activity among recovery years and soil depths

The current study demonstrated that cropland abandonment mainly increased soil microbial activity in the $0-20 \mathrm{~cm}$ layers, supporting the findings from previous studies (Xiao et al., 2020; Xu et al., 2020a). Soil microbial activity is regulated by many factors, including climate, vegetation, and soil (Nannipieri et al., 2018). Vegetation restoration affects the spatiotemporal dynamics of soil microbial activity, influencing the microclimate, plant biomass, above- and below-ground carbon input, and soil physicochemical properties (Caldwell, 2005).
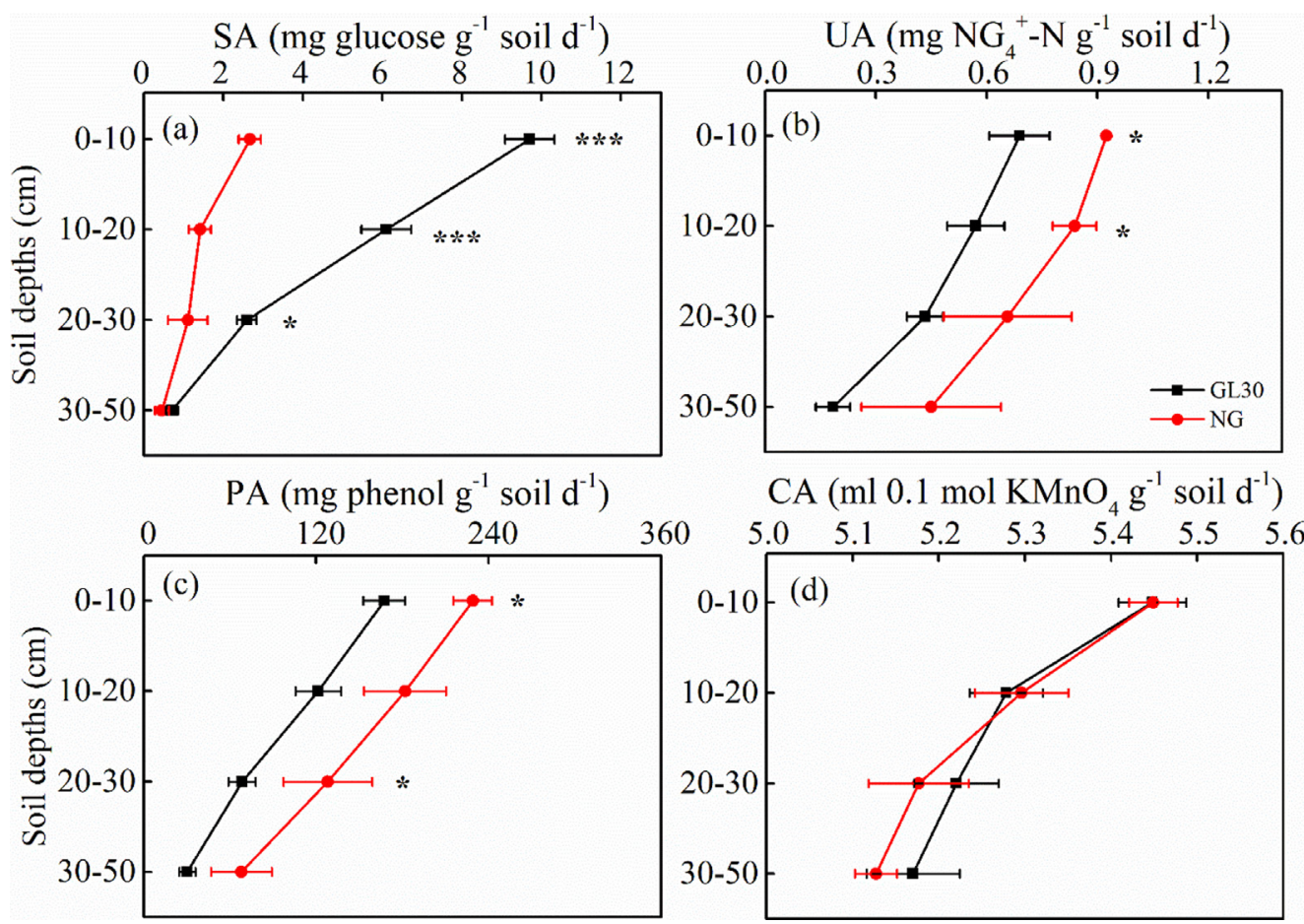

Fig. 4. Soil enzyme activity ((a) soil saccharase activity (SA), (b) soil urease activity (UA), (c) soil phosphatase activity (PA) and (d) soil catalase activity (CA)) at different soil depths in a grassland (GL) at 30 years of recovery compared to that in a natural grassland (NG). Note: * denotes significant difference at $P<0.05 ; * * *$ denotes significant differences at $P<0.001$. 

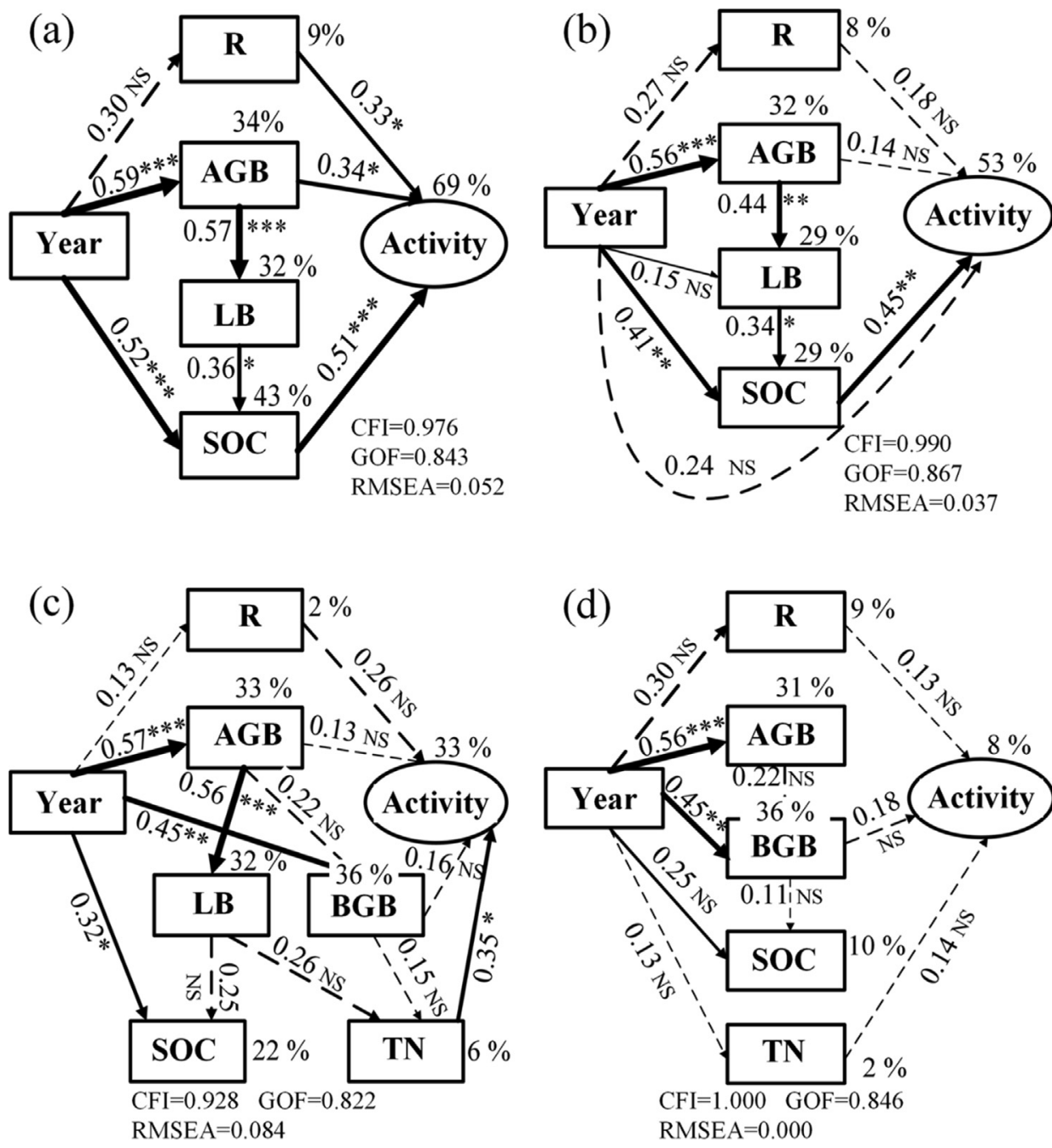

Fig. 5. Structural equation models (SEMs) demonstrating the direct and indirect effects of recovery years on soil microbial activity at: (a) 0-10 cm soil depth; (b) 10-20 cm soil depth; (c) 20-30 cm soil depth; and (d) 30-50 cm soil depth. Note: CFI, comparative fit index; GOF, goodness of fit; RMSEA, root mean square error of approximation; Solid arrows indicate significant relationships ( $\mathrm{p}>0.05$ ); dashed arrows indicate insignificant path coefficients; numbers above arrows indicate standardized path coefficients. Values associated with arrows indicate standardized path coefficients $(*, P<0.05 ; *$, $P<0.01 ; * * *, P<0.001 ;$ NS, insignificant difference); R, Margalef richness index; AGB, aboveground biomass; BGB, belowground biomass; LB, litter biomass; SOC, soil organic carbon; TN, soil total nitrogen.
First, after cropland abandonment, reduced nutrient loss and large inputs of organic matter result in more nutrients for microbial growth. This can explain the substantial increase in microbial biomass (Burns et al., 2013; Pausch and Kuzyakov, 2018). After cropland is abandoned, vegetation gradually recovers, with an overall increase in the amount of litter (Fig. S1 a), root residue, and secretions being returned to the soil (Xu et al., 2020b). These parameters provide more substrate for microorganisms, which produce more soil enzymes in response (Kurganova et al., 2020; Pausch and Kuzyakov, 2018). Second, compared with croplands, grasslands have more developed ventilation tissues (roots). These tissues excrete more microorganisms, thus changing microbial activity (Caldwell, 2005). Third, soil structure and quality are improved, resulting in a significant increase in the metabolism of microorganisms (Cui et al., 2019; Kalinina et al., 2019).

The current study also showed that soil microbial activity (except SA and PA) changes were poor in the $20-50 \mathrm{~cm}$ soil layers. According to the resource allocation theory, soil microbial activity is positively correlated with nutrient availability (Xu et al., 2017). Topsoil directly receives soil nutrients from the litter and root exudates. Overall soil microbial activity decreased with soil depth for all years in our study, corroborating the results of previous studies (Könönen et al., 2018). This may be because of favorable soil ventilation conditions, as well as more litter and humus in the topsoil, which enhance the survival and reproduction of microorganisms (Sinha et al., 2009). With increasing soil depth, SOC content and root biomass decrease (Berger et al., 2002; Xu et al., 2019), ultimately causing soil microbial activity to decline.

In contrast, in the upper soil layer, secretions from plants, animals, and microorganisms accumulate, with strong physiological activity enhancing the secretion of enzymes (Sinha et al., 2009; Yi et al., 2010). $\mathrm{qCO}_{2}$ is often used as a sensitive indicator of carbon use efficiency by soil microbes (Dilly and Munch, 1996). Thus, a decrease in $\mathrm{qCO}_{2}$ after cropland abandonment enhances the carbon use efficiency of soil microbes, soil microbial biomass, and humus (Dilly and Munch, 1996). In parallel, when a low $\mathrm{qCO}_{2}$ indicates that microorganisms are more stable and mature (Huang et al., 2009). The current study showed that soil biological functions gradually recover over time, with damage to soil microbial diversity gradually decreasing after several years of vegetation restoration. In addition, $\mathrm{qCO}_{2}$ did not change significantly with recovery years in the $10-50 \mathrm{~cm}$ layers. Previous studies showed that $\mathrm{qCO}_{2}$ is significantly affected by soil organic matter (Huang et al., 2009). Thus, $\mathrm{qCO}_{2}$ might not be sensitive in the $10-50 \mathrm{~cm}$ layers because changes to SOC sensitivity in this layer were lower than those in the $0-10 \mathrm{~cm}$ layer (Fig. S1 c).

Previous studies showed that soil nutrients fail to reach NG levels after cropland abandonment (Xu et al., 2020c). More importantly, the current study showed that soil microbial activity (except SA and CA) was lower in GL30 compared to NG in the $0-10 \mathrm{~cm}$ layer. This result might be attributed to the lower plant biomass, coverage, and plant diversity under GL30 compared to NG (Chang et al., 2017). These disparities lead to lower litter and energy availability for soil microorganisms in grassland, due to more decaying roots (Bastida et al., 2008). In parallel, differences to vegetation biomass can alter the organic matter input to the soil, with soil nutrients failing to reach the levels documented in NG (Fig. S2). In addition, a previous study showed 
that the composition of soil microorganisms in abandoned cropland is simpler than that in NG (Thoms et al., 2010). Therefore, the restoration of soil microbial activity might be limited by soil nutrient content during cropland abandonment. Thus, the recovery of soil microorganisms is possible; however, the complete recovery of soil microbial activity was not detected in our chronosequence. Therefore, a number of years are required for the complete recovery of microbial activity after cropland abandonment in this semi-arid environment.

\subsection{Factors driving soil microbial activity along the grassland restoration chronosequence at different soil depths}

Our results support the general theoretical predictions and empirical findings that soil microbial activity is regulated by recovery time (Chen et al., 2019). Our study showed that plant characteristics and soil physicochemical parameters contribute towards predicting soil microbial activity after cropland abandonment. In particular, R, AGB, LB, and $S O C$ were the major predictors of changes in soil microbial activity in the 0-20 cm soil layers. R, AGB, LB, BGB, TN, and SOC were the major predictors of change in soil microbial activity in the $30-50 \mathrm{~cm}$ soil layers, based on the best-fitting models.

Our study demonstrated that changes in R, AGB, and SOC explained a large proportion of the variability in soil microbial activity in the 0-20 cm layers. This coincided with patterns in plant, soil, and soil microorganism relationships in the grassland community (Chen et al., 2019). As the number of years of recovery increased, plant diversity and abundance at the plant community level also increased. Higher diversity and abundance cause vegetation productivity and topsoil SOC content to increase (Kurganova et al., 2020). The plant biomass (Fig. S1 a), plant species diversity (Fig. S1 b), and soil nutrients $(0-20 \mathrm{~cm}$ layers) (Fig. S1 c) overall increased with recovery years (Xu et al., 2020b). These positive interactions caused soil microbial activity to increase (Chen et al., 2019). Higher levels of carbon input and better microclimate conditions associated with plant diversity generate more active and diverse microbes and higher enzyme activities (Lange et al., 2015; Kurganova et al., 2018). This high abundance and biomass subsequently reduces evaporation of topsoil moisture, which, in turn, promotes higher soil microbial activity (Lange et al., 2014). Furthermore, high organic carbon content promotes the respiration of soil microbes, which increases the absorption of nutrients (Thomas et al., 2005) and, hence, soil microbial activity. We showed that AGB had a direct and significantly positive effect on $\mathrm{LB}$, with this effect being enhanced by LB. An RDA showed that AGB, R, and SOC were positively correlated with MBC, MBN, BR, SA, UA, PA, and CA. Thus, plant and soil characteristics influence soil microbial activity, which changed along the grassland restoration chronosequence (Fig. 6a, b and Table S1). The biomass and respiration of microbes, along with enzyme activity, responded to SOC in the soil, corroborating R and AGB; however, these responses were higher for SOC when compared with plant characteristics (Fig. 7).

$\mathrm{R}, \mathrm{AGB}, \mathrm{BGB}$, and TN explained a unique proportion of soil microbial activity in the $20-30 \mathrm{~cm}$ layer. In comparison, the direct effects of $\mathrm{R}, \mathrm{AGB}$, and SOC gradually weakened in the model. AGB becomes increasingly concentrated in the soil surface through the formation of litter (Chen et al., 2019); consequently, the effect of microbial activity decline. However, AGB indirectly affected soil microbial activity through its effect on BGB. Previous studies showed that the properties of the topsoil mainly depend on AGB, whereas the properties of deeper layers mainly depend on the roots of vegetation (Vesterdal et al., 2002). The RDA showed that AGB, BGB, LB, and SOC were positively correlated with MBC, BR, SA, UA, and PA (Fig. $6 \mathrm{c}$ and Table S1). Thus, AGB, $\mathrm{BGB}, \mathrm{LB}$, and SOC could be used to indicate changes in soil microbial activity in the $20-30 \mathrm{~cm}$ layer. R, BGB, and TN weakly affected soil microbial activity, while the direct effects of AGB and SOC disappeared in the $30-50 \mathrm{~cm}$ layer. Our study showed that AGB and SOC did not drive variation in soil microbial activity at soil depths $>30 \mathrm{~cm}$.
Furthermore, previous studies have shown that roots are mainly distributed in the 0-30 cm layers (Ugawa et al., 2010). Consequently, R, $\mathrm{BGB}$, and TN only had minor effects on soil microbial activity.

Our study showed that $\mathrm{R}$ affected soil microbial activity at all soil depths; however, the overall influence of $\mathrm{R}$ on microbial activity gradually declined with increasing soil depth (Fig. 7). During the process of cropland abandonment, plant species richness represents a major factor regulating changes in soil microbial activity at different soil depths. Specifically, high plant species richness enhances soil microbial activity (Fornara and Tilman, 2010). Guenay et al. (2013) demonstrated that plant species richness has a greater effect on microbial activity in deeper soil. In comparison, other studies showed that this effect is stronger in the topsoil and weaker in deeper soil (Steinbeiss et al., 2010). This difference might be influenced by vegetation richness increasing with recovery time. Higher productivity might enhance soil carbon and nutrient input to the soil, with the nutrient content of soil microorganisms gradually increasing (Lange et al., 2015; Ma and Chen, 2018); however, nutrient input decreases with increasing soil depth (Fornara and Tilman, 2010). Therefore, when assessing changes in soil microbial activity, the relationship between soil microbial activity, plants, and soil at greater soil depths must be clarified. Our study showed that the overall effect of recovery time on soil microbial activity gradually decreased with increasing soil depth $(<0.2$ in the $30-50 \mathrm{~cm}$ soil layer) (Fig. 6b). Thus, vegetation restoration has little effect on microbial activity in deep soil layer, directly or indirectly. This phenomenon was confirmed in our study, showing that the soil microbial activity changes was poor in the $30-50 \mathrm{~cm}$ layer, even after 30 years.

\subsection{Limitations and uncertainties}

Our research identified the factors driving changes in soil microbial activity at different soil depths after cropland abandonment on the Loess Plateau. However, Kim et al. (2019) reported that soil moisture has significant effects on soil microbial biomass and enzyme activities, which might be related to the soil microclimate. After cropland abandonment, the growth of vegetation led to an increase in vegetation coverage (Xu et al., 2020b). Some studies found that vegetation growth will increase shade and reduce water evaporation, thereby creating a warm and humid environment for soil microorganisms, which is conducive to the growth and activity of microorganisms (Settineri et al., 2018). Meanwhile, soil temperature is also an important factor affecting soil microbial activity (Yang et al., 2017), as warm conditions can promote microbial metabolism (Alvarez et al., 1995). Additionally, $\mathrm{pH}$ can also affect soil microbial biomass and general microbiological rates (Hinojosa et al., 2004; Speir et al., 1999). Therefore, in our study, it is not clear whether the increase in soil microbial activity after the cropland abandonment is affected by soil moisture, temperature, and $\mathrm{pH}$. Further research on soil microbial activity should be conducted to investigate these variables. Furthermore, we only assessed the impact of recovery of grassland on soil microbial activity, without considering the type of cropland, shrubland and forestland after vegetation restoration, which may lead to uncertainty in our results. Thus, future studies should consider different ecosystems. Additionally, altered precipitation regimes have a marked impact on global climate change (precipitation and temperature), thus having a significant effect on soil microbial activity. For example, in a meta-analysis of 70 published articles, Ren et al. (2017) found that higher precipitation results in significantly higher soil microbial activity. However, our understanding of the factors driving these changes in soil microbial activity under different rainfall conditions in still insufficient. Therefore, there is an urgent need to conduct more field experiments on a larger spatial scale (such as the global scale) to determine the drivers of soil microbial activity under different environmental conditions (e.g., rainfall). 

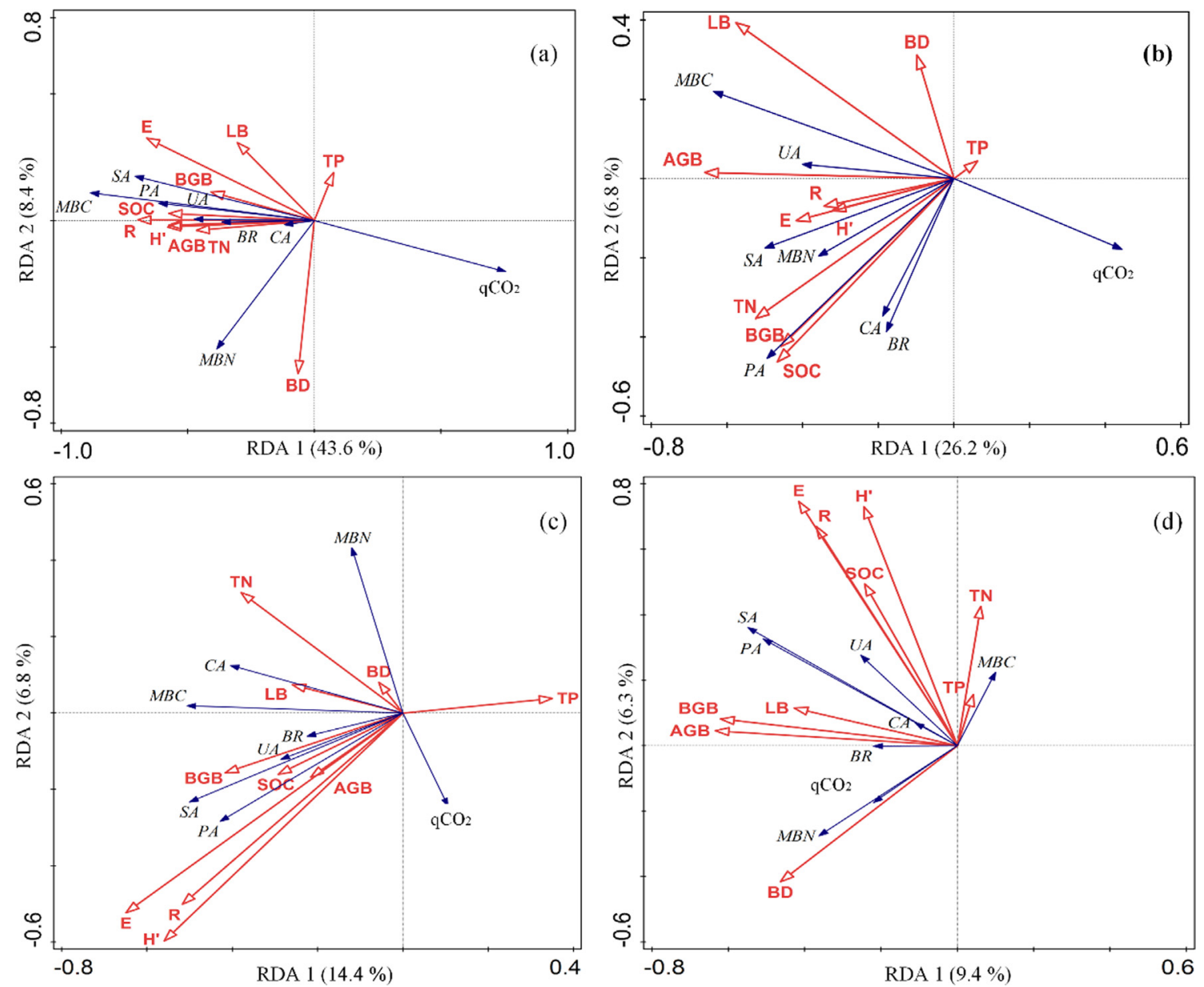

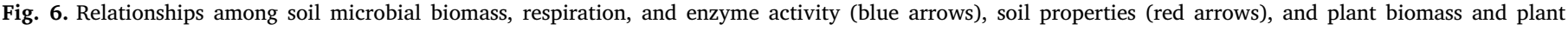

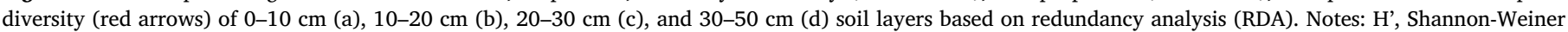

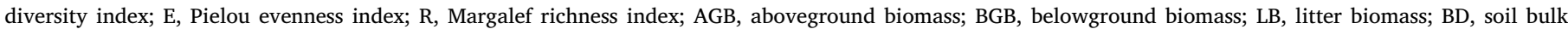

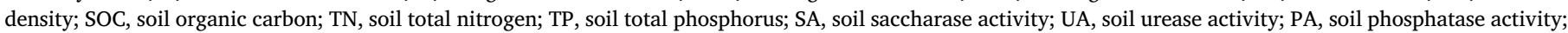

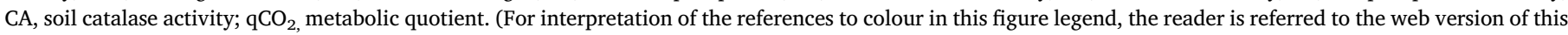
article.)

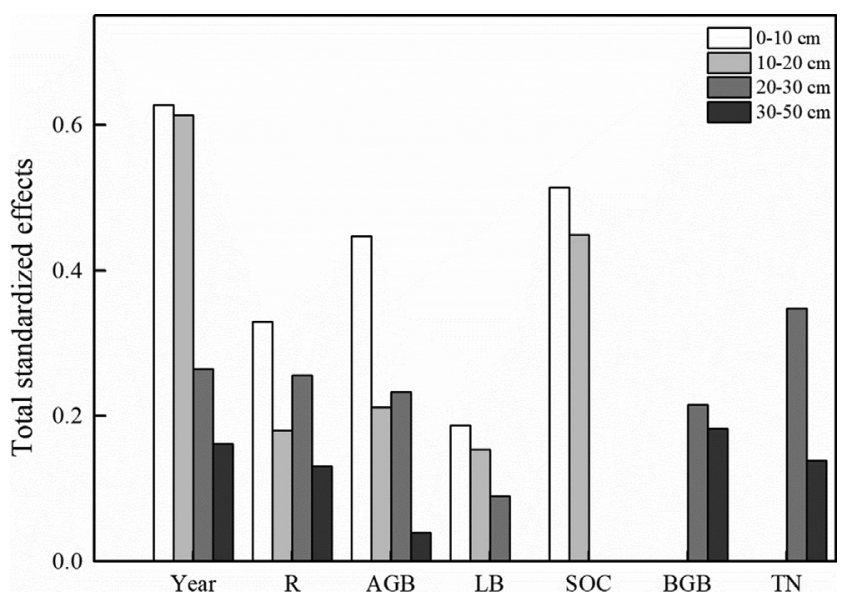

Fig. 7. Total standardized effects for the indexes at different soil depths from structural equation models (SEMs). Note: R, Margalef richness index; AGB, aboveground biomass; BGB, belowground biomass; LB, litter biomass; SOC, soil organic carbon; TN, soil total nitrogen.

\subsection{Implications of our studies}

Our research showed that overall soil microbial activity in the 0-20 cm soil layers increased after cropland abandonment and identified the effects of plant characteristics and soil physicochemical parameters on soil microbial activity at different soil depths. Previous studies reported that plant diversity, plant biomass, and soil nutrients are important factors affecting soil microbial biomass, enzyme activity, and respiration (Chen et al., 2019; Lange et al., 2015; Na et al., 2019), without considering the effect of soil depth. However, we found that soil depth is important for determining the drivers of soil microbial activity. In our study, soil microbial activity in the $0-20 \mathrm{~cm}$ layers was affected by plant species richness, aboveground biomass, and SOC. However, as soil depth increased, plant species richness, belowground biomass, and soil total nitrogen became the main factors influencing soil microbial activity. As our study was based on a relatively longer recovery sequence $(2,5,8,11,15,18,26$, and 30 years) of grassland after cropland abandonment, it can be used as a reference for the driving factors of soil microbial activity after cropland abandonment in arid and semi-arid areas (Loess Plateau of China). We found that plant characteristics and soil physicochemical parameters provide sufficient information for assessing changes in soil microbial activity with soil depth. Therefore, we propose that plant species richness, aboveground biomass, and soil organic carbon should be used to evaluate changes in soil microbial activity in the $0-20 \mathrm{~cm}$ layers, whereas plant species 
richness, belowground biomass, and soil total nitrogen should be used to evaluate changes in soil microbial activity in the $20-50 \mathrm{~cm}$ layers. This could be widely applied to the grassland restoration process in arid and semi-arid areas.

\section{Conclusion}

Our study provided direct evidence that cropland abandonment promoted soil microbial biomass, enzyme activity, and respiration in the surface soil $(0-20 \mathrm{~cm}$ soil layers), with these microbial properties increasing linearly with time since abandonment. We also showed that soil microbial biomass, enzyme activity (except SA and PA), and respiration changes were poor in the $20-50 \mathrm{~cm}$ soil layers with time since abandonment. This indicates that cropland abandonment has a greater effect on the surface soil microbial environment, and therefore, it could have a large impact on nutrient cycling in the surface soil. The growth of grass is strongly influenced by the surface soil environmental condition; thus, the increase in microbial activity in the surface soil could play a vital role in improving vegetation productivity. Recovery years affected changes in soil microbial activity in different soil layers, either directly or indirectly, based on plant characteristics and soil physicochemical parameters. Plant species richness, aboveground biomass, and soil organic carbon represented key drivers of variation in soil microbial activity in the $0-20 \mathrm{~cm}$ soil layer. As soil depth increased, plant species richness, belowground biomass, and soil total nitrogen became the main factors influencing these changes. In addition, the overall effect of recovery years on soil microbial activity gradually decreased with soil depth, explaining $69 \%, 53 \%, 33 \%$, and $8 \%$ in the four soil layers, respectively. In conclusion, we identified the drivers of changes in soil microbial activity after cropland abandonment. This study highlights the importance of plant production and diversity, as well as soil physicochemical parameters, in driving changes in soil microbial activity at different soil depths. Further studies are needed to assess the role of soil moisture, temperature, and $\mathrm{pH}$ in driving the observed changes in soil microbial activity. Additionally, there is an urgent need to perform more field experiments in different ecosystems, such as croplands, grasslands, and forests, and at larger spatial scales to identify the factors driving changes in soil microbial activity under different ecosystems and environmental conditions.

\section{Declaration of Competing Interest}

The authors declared that there is no conflict of interest.

\section{Acknowledgements}

This work was supported by the Natural Science Foundation of China (41771557), National Key Research and Development Program of China (2016YFC0501707), and State Key Laboratory of Soil Erosion and Dryland Farming on the Loess Plateau (A314021402-2017). We would like to thank Editage (www.editage.cn) for English language editing.

\section{Appendix A. Supplementary material}

Supplementary data to this article can be found online at https:// doi.org/10.1016/j.catena.2020.104774.

\section{References}

Alvarez, R., Santanatoglia, O.J., Garcîa, R., 1995. Effect of temperature on soil microbial biomass and its metabolic quotient in situ under different tillage systems. Biol. Fertil. Soils 19, 227-230.

Bastida, F., Barberá, G.G., García, C., Hernández, T., 2008. Influence of orientation, vegetation and season on soil microbial and biochemical characteristics under semiarid conditions. Appl. Soil Ecol. 38, 62-70.

Beijing, 1995. Plant community diversity in ongling mountain, Beijing, China:II. Speciea richness, evenness and species diversities. Acta Ecologica Sinica.

Berger, T.W., Neubauer, C., Glatzel, G., 2002. Factors controlling soil carbon and nitrogen stores in pure stands of Norway spruce (Picea abies) and mixed species stands in Austria. For. Ecol. Manage. 159, 3-14.

Bollen, K.A., 1998. Structural equations with latent variables. New York John Wiley \& Sons. 35, 289-308.

Bremner, J.M., Sparks, D.L., Page, A.L., Helmke, P.A., Loeppert, R.H., Soltanpour, P.N., Tabatabai, M.A., Johnston, C.T., Sumner, M.E., 1982. Nitrogen - total. Methods Soil Anal. Chem. Methods Part 72, 532-535.

Burns, R.G., DeForest, J.L., Marxsen, J., Sinsabaugh, R.L., Stromberger, M.E., Wallenstein, M.D., Weintraub, M.N., Zoppini, A., 2013. Soil enzymes in a changing environment: current knowledge and future directions. Soil Biol. Biochem. 58, 216-234.

Caldwell, B.A., 2005. Enzyme activities as a component of soil biodiversity: a review. Pedobiologia 49, 637-644.

Chang, X.F., Chai, Q.L., Wu, G.L., Zhu, Y.J., Li, Z.W., Yang, Y.F., Wang, G.L., 2017. Soil organic carbon accumulation in abandoned croplands on the loess plateau. Land Degrad. Dev. 28, 1519-1527.

Chen, C., Chen, H.Y.H., Chen, X., Huang, Z., 2019. Meta-analysis shows positive effects of plant diversity on microbial biomass and respiration. Nat. Commun. 10.

Cui, Y., Fang, L., Guo, X., Han, F., Ju, W., Ye, L., Wang, X., Tan, W., Zhang, X., 2018. Ecoenzymatic stoichiometry and microbial nutrient limitation in rhizosphere soil in the arid area of the northern Loess Plateau. China. Soil Biol. Biochem. 116, 11-21.

Cui, Y., Fang, L., Guo, X., Wang, X., Zhang, Y., Li, P., Zhang, X., 2019. Natural grassland as the optimal pattern of vegetation restoration in arid and semi-arid regions: Evidence from nutrient limitation of soil microbes. Sci. Total Environ. 648, 388-397.

de Medeiros, E.V., Duda, G.P., Rodrigues Dos Santos, L.A., de Sousa Lima, J.R., AlmeidaCortêz, J.S.D., Hammecker, C., Lardy, L., Cournac, L., 2017. Soil organic carbon, microbial biomass and enzyme activities responses to natural regeneration in a tropical dry region in Northeast Brazil. Catena 51, 137-146.

Dilly, O., Munch, J.C., 1996. Microbial biomass content, basal respiration and enzyme activities during the course of decomposition of leaf litter in a black alder (Alnus glutinosa (L.) Gaertn.) forest. Soil Biol. Biochem. 28, 1073-1081.

Fornara, D., Tilman, D., 2010. Plant functional composition influences rates of soil carbon and nitrogen accumulation. J. Ecol. 96, 314-322.

Geisseler, D., Scow, K.M., 2014. Long-term effects of mineral fertilizers on soil microorganisms- a review. Soil Biol. Biochem. 75, 54-63.

Guan, S.Y., 1986. Soil Enzyme and its Research Approaches China. Agri. Press, Beijing. Guenay, Y., Ebeling, A., Steinauer, K., Weisser, W.W., Eisenhauer, N., 2013. Transgressive overyielding of soil microbial biomass in a grassland plant diversity gradient. Soil Biol. Biochem. 60, 122-124.

Hinojosa, M.B., García-Ruíz, R., Egla, B.V., Carreira, J.A., 2004. Microbiological rates and enzyme activities as indicators of functionality in soils affected by the Aznalcóllar toxic spill. Soil Biol. Biochem. 36, 1637-1644.

Huang, Y., An, S., Xue, H., 2009. Responses of soil microbial biomass C and N and respiratory quotient $\left(\mathrm{qCO}_{2}\right)$ to revegetation on the Loess Hilly Gully region. Actae Ecologica Sinica. 29, 2811-2818.

Jenkinson, D.S., Brookes, P.C., Powlson, D.S., 2004. Measuring soil microbial biomass. Soil Biol. Biochem. 36, 5-7.

Kalinina, O., Cherkinsky, A., Chertov, O., Goryachkin, S., Kurganova, I., de Gerenyu, V.L., Lyuri, D., Kuzyakov, Y., Giani, L., 2019. Post-agricultural restoration: implications for dynamics of soil organic matter pools. Catena 181, 104096.

Kim, S., Li, G., Han, S.H., Kim, C., Lee, S.T., Son, Y., 2019. Microbial biomass and enzymatic responses to temperate oak and larch forest thinning: influential factors for the site-specific changes. Sci. Total Environ. 651 (PT.2), 2068-2079.

Könönen, M., Jauhiainen, J., Straková, P., Heinonsalo, J., Laiho, R., Kusin, K., Limin, S., Vasander, H., 2018. Deforested and drained tropical peatland sites show poorer peat substrate quality and lower microbial biomass and activity than unmanaged swamp forest. Soil Biol. Biochem. 123, 229-241.

Kristiina, K., Auffret, M.D., Dungait, J.A.J., Hopkins, D.W., Prosser, J.I., Singh, B.K., JensArne, S., Wookey, P.A., Agren, G.R.I., Maria-Teresa, S., 2014. Temperature sensitivity of soil respiration rates enhanced by microbial community response. Nature 513, $81-84$.

Kurganova, I., Merino, A., de Gerenyu, V.L., Barros, N., Kalinina, O., Giani, L., Kuzyakov, Y., 2020. Mechanisms of carbon sequestration and stabilization by restoration of arable soils after abandonment: A chronosequence study on Phaeozems and Chernozems. Geoderma 354, 113882.

Kurganova, I., Gerenyu, V., Mostovaya, A., Ovsepyan, L., Baeva, Y., 2018. Effect of re forestation on microbiological activity of postagrogenic soils in european russia. Contemp. Probl Ecol. 11, 704-718.

Liang, C., Schimel, J.P., Jastrow, J.D., 2017. The importance of anabolism in microbial control over soil carbon storage. Nat. Microbiol. 2, 17105.

Lange, M., Habekost, M., Eisenhauer, N., Roscher, C., Bessler, H., Engels, C., Oelmann, Y., Scheu, S., Wilcke, W., Schulze, E.D., Gleixner, G., 2014. Biotic and abiotic properties mediating plant diversity effects on soil microbial communities in an experimental grassland. PLoS ONE 9, e96182.

Lange, M., Eisenhauer, N., Sierra, C.A., Bessler, H., Engels, C., Griffiths, R.I., Melladovázquez, P.G., Malik, A.A., Roy, J., Scheu, S., 2015. Plant diversity increases soil microbial activity and soil carbon storage. Nat. Commun. 6, 6707.

Liu, Y., Dang, Z., Tian, F., Wang, D., Wu, G., 2017. Soil organic carbon and inorganic carbon accumulation along a 30-year grassland restoration chronosequence in semiarid Regions (China). Land Degrad. Dev. 28, 189-198.

Ma, Z., Chen, H.Y.H., 2018. Positive species mixture effects on fine root turnover and mortality in natural boreal forests. Soil Biol. Biochem. 121, 130-137.

Mooshammer, M., Wanek, W., Hammerle, I., Fuchslueger, L., Hofhansl, F., Knoltsch, A., Schnecker, J., Takriti, M., Watzka, M., Wild, B., Keiblinger, K.M., ZechmeisterBoltenstern, S., Richter, A., 2014. Adjustment of microbial nitrogen use efficiency to 
carbon: nitrogen imbalances regulates soil nitrogen cycling. Net. Commun. 5, 3694.

Na, X., Yu, H., Wang, P., Zhu, W., Niu, Y., Huang, J., 2019. Vegetation biomass and soil moisture coregulate bacterial community succession under altered precipitation regimes in a desert steppe in northwestern China. Soil Biol. Biochem. 136, 107520.

Nannipieri, P., Trasar-Cepeda, C., Dick, R.P., 2018. Soil enzyme activity: a brief history and biochemistry as a basis for appropriate interpretations and meta-analysis. Biol. Fertil. Soils 54, 11-19.

Nelson, D.W., Sommers, L.E., 1982. Total carbon, organic carbon and organic matter. Methods of Soil Analysis Part 2. Chem. Microbial Properties.

Pausch, J., Kuzyakov, Y., 2018. Carbon input by roots into the soil: quantification of rhizodeposition from root to ecosystem scale. Glob. Change Biol. 24, 1-12.

Powlson, D.S., Jenkinson, D.S., 1976. The effects of biocidal treatments on metabolism in soil-II. Gamma irradiation, autoclaving, air-drying and fumigation. Soil Biol. Biochem. 8, 179-188.

Raj, K.N., Watanabe, T., 2006. Abandonment of agricultural land and its consequences: a case study in the Sikles area, Gandaki Basin, Nepal Himalaya. Mt. Res. Dev. 26, 32-40.

Ren, C.J., Zhao, F.Z., Shi, Z., Chen, J., Han, X.H., Yang, G.H., Feng, Y.Z., Ren, G.X., 2017. Differential responses of soil microbial biomass and carbon-degrading enzyme activities to altered precipitation. Soil Biol. Biochem. 115, 1-10.

Schade, J.D., Kyle, M., Hobbie, S.E., Fagan, W.F., Elser, J.J., 2003. Stoichiometric tracking of soil nutrients by a desert insect herbivore. Ecol. Lett. 6, 96-101.

Settineri, G., Mallamaci, C., Mitrović, M., Sidari, M., Muscolo, A., 2018. Effects of different thinning intensities on soil carbon storage in Pinus laricio forest of Apenneine South Italy. Eur. J. For. Res. 137, 131-141.

Shi, H., Shao, M.A., 2000. Soil and water loss from the loess plateau in China. J. Arid Environ. 45.

Sinha, S., Masto, R.E., Ram, L.C., Selvi, V.A., Srivastava, N.K., Tripathi, R.C., George, J., 2009. Rhizosphere soil microbial index of tree species in a coal mining ecosystem. Soil Biol. Biochem. 41, 1824-1832.

Singh, B.K., Bardgett, R.D., Smith, P., Reay, D.S., 2010. Microorganisms and climate change: terrestrial feedbacks and mitigation options. Nat. Rev. Microbiol. 8, 779-790.

Speir, T.W., Kettles, H.A., Percival, H.J., Parshotam, A., 1999. Is soil acidification the cause of biochemical response when soils are amended with heavy metal salts? Soil Biol. Biochem. 31, 1953-1961.

Spohn, M., PoTsch, E.M., Eichorst, S.A., Woebken, D., Wanek, W., Richter, A., 2016. Soil microbial carbon use efficiency and biomass turnover in a long-term fertilization experiment in a temperate grassland. Soil Biol. Biochem. 97, 168-175.

Steinbeiss, S., Beßler, H., Engels, C., Temperton, V.M., Buchmann, N., Roscher, C., Kreutziger, Y., Baade, J., Habekost, M., Gleixner, G., 2010. Plant diversity positively affects short-term soil carbon storage in experimental grasslands. Glob. Change Biol. 14, 2937-2949.

Thomas, B., Newman, J.A., Silverman, B.W., Turner, S.L., Lilley, A.K., 2005. The contribution of species richness and composition to bacterial services. Nature 436 , 1157-1160.

Thoms, C., Gattinger, A., Jacob, M., Thomas, F.M., Gleixner, G., 2010. Direct and indirect effects of tree diversity drive soil microbial diversity in temperate deciduous forest. Soil Biol. Biochem. 42, 1558-1565.
Ugawa, S., Miura, S., Iwamoto, K., Kaneko, S., Fukuda, K., 2010. Vertical patterns of fine root biomass, morphology and nitrogen concentration in a subalpine fir-wave forest. Plant Soil 335, 469-478.

Vance, E.D., Brookes, P.C., Jenkinson, D., 1987. An extraction method for measuring microbial biomass carbon. Soil Biol. Biochem. 19, 703-707.

Vesterdal, L., Ritter, E., Gundersen, P., 2002. Change in soil organic carbon following afforestation of former arable land. For. Ecol. Manage. 169, 137-147.

Wang, B., Xue, S., Liu, G.B., Zhang, G.H., Li, G., Ren, Z.P., 2012. Changes in soil nutrient and enzyme activities under different vegetations in the loess plateau area, northwest china. Catena. 92, 186-195.

Xiao, L., Liu, G.B., Li, P., Li, Q., Xue, S., 2020. Ecoenzymatic stoichiometry and microbial nutrient limitation during secondary succession of natural grassland on the Loess Plateau. China. Soil Tillage Res. 200, 104605.

Xu, H.W., Qu, Q., Li, P., Guo, Z., Wulan, E., Xue, S., 2019. Stocks and Stoichiometry of Soil Organic Carbon, Total Nitrogen, and Total Phosphorus after Vegetation Restoration in the Loess Hilly Region China. Forests 10, 27.

Xu, H.W., Qu, Q., Lu, B.B., Li, P., Xue, S., Liu, G.B., 2020a. Response of soil specific enzyme activity to vegetation restoration in the Loess hilly region of China. Catena. 191, 104564.

Xu, H., Wang, X.K., Qu, Q., Zhai, J.Y., Song, Y.H., Qiao, L.L., Liu, G.B., Xue, S., 2020b. Cropland abandonment altered grassland ecosystem carbon storage and allocation and soil carbon stability in the Loess Hilly Region. China. Land Degrad Dev. 31, 1001-1013.

Xu, H.W., Qu, Q., Wang, M.G., Li, P., Li, Y.Z., Xue, S., Liu, G.B., 2020c. Soil organic carbon sequestration and its stability after vegetation restoration in the Loess Hilly Region China. Land Degrad. Dev. 31, 568-580.

Xu, Z., Yu, G., Zhang, X., He, N., Wang, Q., Wang, S., Wang, R., Ning, Z., Jia, Y., Wang, C., 2017. Soil enzyme activity and stoichiometry in forest ecosystems along the NorthSouth Transect in eastern China (NSTEC). Soil Biol. Biochem. 104, 152-163.

Xue, S., Yang, X., Liu, G., Gai, L., Zhang, C., Ritsema, C.J., Geissen, V., 2017. Effects of elevated $\mathrm{CO} 2$ and drought on the microbial biomass and enzymatic activities in the rhizospheres of two grass species in Chinese loess soil. Geoderma 286, 25-34.

Yang, Y., Geng, Y., Zhou, H., Zhao, G., Wang, L., 2017. Effects of gapsinthe forest canopyon soil microbial communities and enzyme activity in a Chinese pine forest. Pedobiologia 61, 51-60.

Yevdokimov, I., Larionova, A., Blagodatskaya, E., 2016. Microbial immobilisation of phosphorus in soils exposed to drying-rewetting and freeze-thawing cycles. Biol. Fertil. Soils 52, 685-696.

Yi, H.Y., Gong, Y.B., Wu, W.H., Wen, W.Q., Chen, L.W., Zhang, J., 2010. Effects of mountain forests-arid valley ecotone in the upper reach of minjiang river vegetation restoration on soil microbial biomass and soil enzyme. J. Soil Water Conserv. 24 145-149.

Zhang, W., Xu, Y., Gao, D., Wang, X., Liu, W., Deng, J., Han, X., Yang, G., Feng, Y., Ren, G., 2019. Ecoenzymatic stoichiometry and nutrient dynamics along a revegetation chronosequence in the soils of abandoned land and Robinia pseudoacacia plantation on the Loess Plateau. China. Soil Biol. Biochem. 134, 1-14.

Zhu, L., Wang, X., Chen, F., Li, C., Wu, L., 2019. Effects of the successive planting of Eucalyptus urophylla on soil bacterial and fungal community structure, diversity, microbial biomass, and enzyme activity. Land Degrad. Dev. 30, 636-646. 